\title{
Estimation of Secchi depth and total suspended solids in water bodies adjourning brick production sites in Benue State, Nigeria
}

\author{
Agera, S. I. N. ${ }^{{ }^{*}}$, Ogwuche, J. A. ${ }^{2}$ and Odo, J. I. ${ }^{3}$ \\ ${ }^{1}$ Department of Forest Production and Products, University of Agriculture, Makurdi, Nigeria. \\ ${ }^{2}$ Department of Geography Benue State University Makurdi, Nigeria. \\ ${ }^{3}$ Department of Fisheries and Aquaculture, University of Agriculture, Makurdi, Nigeria. \\ *Corresponding author. Email: agerastephen@yahoo.com; Tel: +2348058484045.
}

Copyright @ 2019 Agera et al. This article remains permanently open access under the terms of the Creative Commons Attribution License 4.0, which permits unrestricted use, distribution, and reproduction in any medium, provided the original work is properly cited.

Received 31st January, 2019; Accepted 13th March, 2019

\begin{abstract}
This study assessed the Secchi depth (or transparency) and total dissolved solids (TDS) of some rivers and streams adjourning brick sites in eight selected Local Government Areas of Benue State (LGAs), Nigeria. The Secchi disk was used in evaluation of Secchi depth. The Cambo Waterproof Tester brand of HANNA digital instrument was used in taking on-site direct measurement of total dissolved solids (TDS). Assessments of both parameters were made for two years (2012 and 2013) at three sampling stations, viz: (a) point of burnt brick production (PBP), (b) downstream of the point of brick production (DBP) and (c) upstream of the point of brick production (UBP). Results showed that there were significant differences between the dry and wet season Secchi depth of all water bodies from all sampled Local Government Areas. During the dry season Secchi depth (or transparency) was lowest at the sampling points PBP followed by DBP, while UBP recorded the highest transparency values for water bodies at burnt brick sites. Total dissolved solids (TDS) followed the same pattern as for transparency. This implies that burnt bricks production lowers Secchi depth or water transparency. There is need to spare riparian buffer strips along rivers or streams adjourning burnt brick sites as this can trap some of the sediment containing eroded soil in running water during the rainy season. Devegetated burnt brick sited need to be afforested to check erosion and decrease sediment resulting from brick production activities.
\end{abstract}

Keywords: Benue State, bricks production, Nigeria, rivers, Secchi depth, sediment, total dissolved solids (TDS), turbidity.

\section{INTRODUCTION}

Turbidity is the measurement of cloudiness or haziness of a fluid caused by large numbers of individual particles of suspended matter that are generally invisible to the naked eye (Wikipedia, 2011). Fluids may contain suspended solid matter consisting of particles of many diverse sizes. Whereas some suspended solids will be large and heavy enough to settle rapidly at the bottom of the container if a liquid sample is left to stand (the settable solids), very small particles will settle only very slowly or not at all if the sample is regularly agitated or the particles are colloidal. These small solid particles cause the liquid to appear turbid. Turbidity can result from soil erosion and runoff that causes water to be brown; this is called clay turbidity
(Wikipedia, 2011). Turbidity can also emanate from tiny suspended plants in water (algal blooms) that causes water to be green; this is called plankton turbidity. Secchi depth is a measure of light penetration into a water body and is a function of the absorption and scattering of light in the water (Lee et al., 1995). According to Lee and his colleagues, there are primarily three factors or characteristics of water which affect the depth to which light will penetrate. One factor is the amount of colour, either in true solution or in a colloidal or suspended form in the water. Colour-causing materials, the forms (dissolved or colloidal) of which are typically controlled by the amounts and forms of iron present, are often described as 
"humics.". Phytoplankton (algae) in the water column also scatters and absorbs light. Therefore, the presence of high concentrations of algae in a water body reduces light penetration and hence reduces Secchi depth. Third, inorganic clastic (erosional) materials scatter and absorb light, reducing the water's transparency. These materials may be derived from erosion of the shoreline, stirring of sediments into the water column, or erosion in the watershed, and may be transported to the water body by tributaries. The stirring can be due to wind-induced currents, activity of organisms such as carp rooting in the sediments, and/or the activities of man, such as boat traffic, dredging,

The most widely used measurement unit for turbidity is the FTU (Formazin Turbidity Units) or FNU (Formazin Nephelometric Units). Turbidity in lakes, reservoirs, channels, and the oceans can be measured using a Secchi disk. This black and white disk is lowered into the water until it can no longer be seen; the Secchi depth is then recorded as a measure of the transparency of the water (inversely related to turbidity). The disk cannot be used in shallow waters where the disk can still be seen on the bottom. An additional device, which may help measuring turbidity in shallow waters, is the turbidity tube.

Soil excavation operations for brick production and other purposes often contribute to urban and rural runoff pollution by loosening large amounts of soil and sediment and allowing them to flow into gutters, storm drains and the local rivers and streams. Sediment is the most common pollutant washed from brick sites, creating multiple problems once it leaves the work site. Sediment clogs the gills of fish, blocks light transmission and increases water temperature, all which harm aquatic life. Sediment also blocks gutters and storm drains increasing the risk of flooding in areas downstream of the work site. Sediment also serves as a transport for other work site pollutants such as pesticides and cleaning solvents (Engineering Department, City of Walker, Michigan, 2012). Sedimentation destroys fish spawning beds, reduces useful storage volume in reservoirs, clogs streams, and makes costly filtration necessary for municipal water supplies. Suspended sediment can reduce aquatic plant life and alter a stream's ecology (Cook et al., 1994))

Brick production activities can lead to the run-off and leaching of nutrients into rivers, streams, estuaries and underground water. The four pollutants of greatest concern are nitrogen, phosphorus, sediment, human and animal faecal matter (Haggerty and Campbell, 2012). Surface mining and deep mining of soil at brick sites can produce acid mine drainage, a flow of liquid that tends to be highly acidic and can contain high levels of potentially toxic metals (U.S. EPA, 2007). Harvesting wood for energy and other products can lead to soil erosion and runoff if proper management practices are not used. This research set out to assess Secchi depth transparency (SDT) and total suspended solids (TDS) in rivers/streams at brick production sites in Benue state.

\section{METHODOLOGY}

This study was conducted in Benue State, Nigeria, located between longitude $6^{\circ} 35^{\prime}$ and $10^{\circ} \mathrm{E}$ and latitude $6^{\circ} 30^{\prime}$ and $8^{\circ} 10^{\prime} \mathrm{N}$. The state has a total land mass of $30,955 \mathrm{~km}^{2}$. The State is made up of 23 local government areas. Benue State is bounded to the north by Nassarawa State, Taraba State to the East, Ebonyi, Cross River and the Repuplic of Camerrom to the south as well as Kogi and Enugu States to the west. Figure 1 is the map of Benue State where the study was conducted. Figure 1 indicates the various sites locations (indicated in red) within the study areas where the study was conducted.

The bricks were mould-box shaped, sun-dried and fired. The bricks as heavy clay products form a major part of the ceramic industry and are used mainly where structural work is involved. Bricks are made from earth, fire, water and air. They are an extremely good thermal-insulating material. In India where there is an extremely fast-growing housing deficit, burnt bricks are the most popular building material, with a current demand estimated at 55 billion bricks per year (Kumar et al., 1998). Morton (1990) identified four main stages in brick-making viz: winning the clay and preparing it, shaping the bricks, drying the green bricks and firing the bricks.

The following rivers and streams were purposively selected for the assessment of Secchi depth and total suspended solids at brick sites: Dura River (in Buruku LGA), $\mathrm{Ngo}$ and Ambighir streams (both in Gboko LGA), Nak stream (in Gwer West LGA), Amire Tamen (in Kwande LGA), Uavande stream and River Sambe (in Konshisha LGA), River Mu and River Benue (both in Makurdi LGA), Sohonor Stream and Amire Kiriki River (both in Ushongo LGA) as well as Aya River (in Vandeikya LGA). Burnt bricks are produced along each of the selected rivers/streams.

Motorised and non-motorised boats were used in transporting the researcher and assistants along large rivers like Rive Benue. The Cambo Waterproof Tester brand of HANNA digital instrument Model HI 96129 was used in taking on-site direct measurement of total dissolved solids (TDS). The reading of the parameters was done by immersing the sensitive probe of the instrument in water at each of the points where assessments were made. Readings were taken twice a month throughout the dry season and the wet seasons for two years (2012 and 2013). Assessment of TDS was undertaken at three stations along the water course, viz: (a) point of burnt brick production (PBP), (b) downstream of the point of brick production (DBP) and (c) upstream of the point of brick production (UBP). The stations DBP and UBP were each approximately $1000 \mathrm{~m}$ away from PBP.

Secchi depth transparency was measured using a Secchi disk equipment. The disk was constructed using a metal plate which was painted alternate black and white to facilitate its being easily sighted. The disk was fastened to a rope. The rope was used to lower the disk on-site vertically into water. The disk was lowered slowly into 


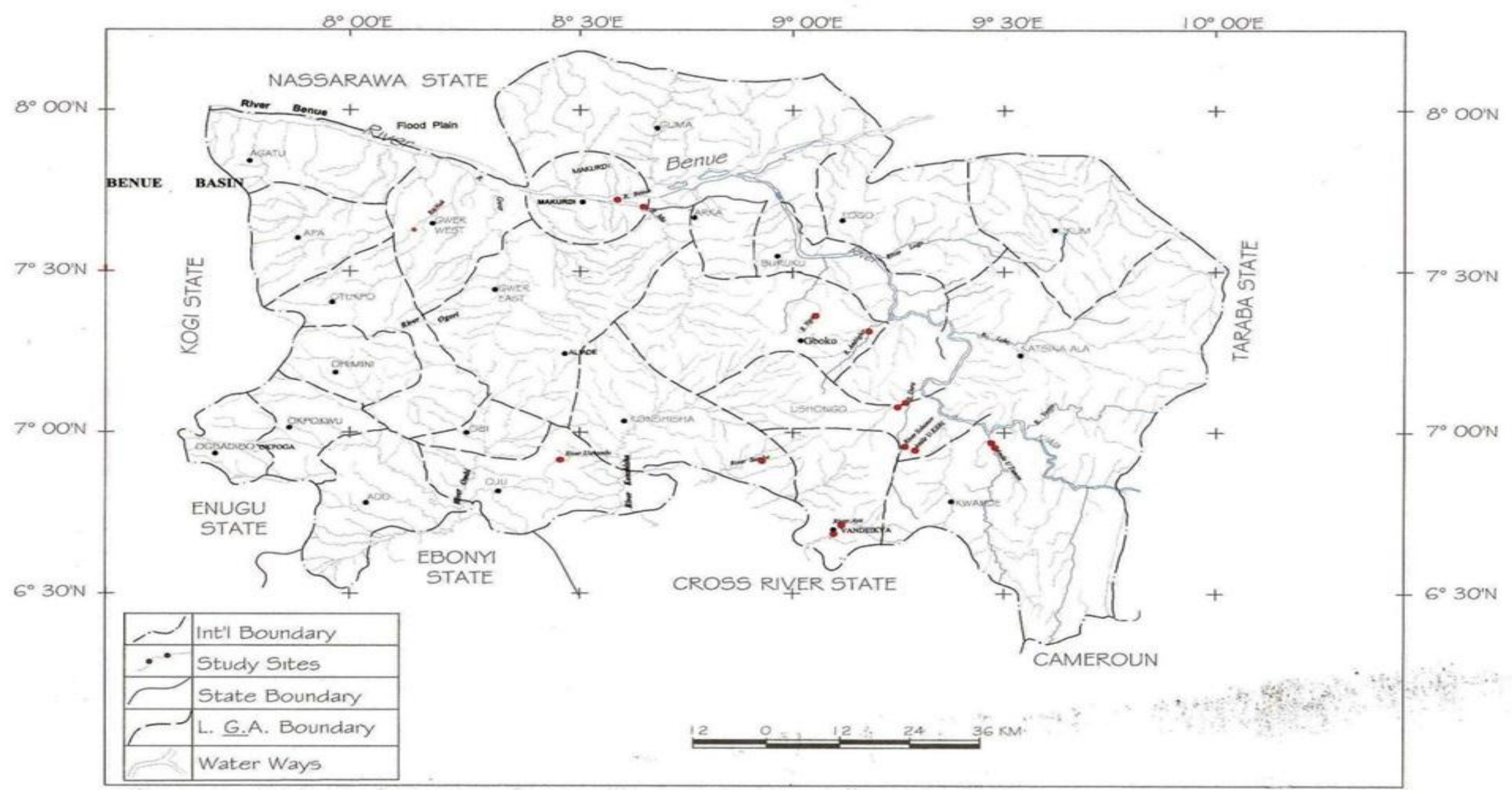

Figure 1. Map of Benue State indicating the study sites (in red).

into water until a point when it could no longer be sighted. A ruler was used to measure the water depth (disappearance) between the metal disc and the point where the rope touched the water surface $\left(d_{1}\right)$. The disk was then slowly pulled towards the water surface until it could be sighted. The second depth (appearance) was also taken using a ruler $\left(d_{2}\right)$. Transparency was measured by finding the average of the two depths (ie disappearance + appearance /2).

\section{RESULTS}

Mean values of Secchi depth or transparency as presented in Table 1 ranged from $12.44 \pm 0.63$ to $50.29 \pm 5.85 \mathrm{~cm}$. Transparency values for Buruku 
Table 1. Mean Secchi depth and total dissolved solids of rivers in Benue State by Local Government Area.

\begin{tabular}{lcc}
\hline \multirow{2}{*}{ Local Government Area } & \multicolumn{2}{c}{ Water quality parameters } \\
\cline { 2 - 3 } & Secchi depth & Total dissolved solids \\
\hline Buruku & $18.39 \pm 0.78^{\mathrm{a}}$ & $61.46 \pm 7.68^{\mathrm{b}}$ \\
Gboko & $27.13 \pm 1.37^{\mathrm{b}}$ & $128.6 \pm 26.60^{\mathrm{c}}$ \\
Gwer & $12.44 \pm 0.63^{\mathrm{a}}$ & $23.51 \pm 0.82^{\mathrm{a}}$ \\
Konshisha & $23.70 \pm 1.44^{\mathrm{ab}}$ & $59.30 \pm 10.4^{\mathrm{b}}$ \\
Kwande & $50.29 \pm 5.85^{\mathrm{d}}$ & $11.46 \pm 0.73^{\mathrm{a}}$ \\
Makurdi & $36.48 \pm 3.55^{\mathrm{c}}$ & $28.97 \pm 4.13^{\mathrm{a}}$ \\
Ushongo & $25.86 \pm 3.10^{\mathrm{ab}}$ & $44.25 \pm 4.01^{\mathrm{ab}}$ \\
Vandeikya & $24.20 \pm 2.07^{\mathrm{ab}}$ & $51.33 \pm 6.47^{\mathrm{b}}$ \\
\hline
\end{tabular}

Means on the same column with the same superscript are not significantly different $(p<0.05)$. SE $=$ Standard error of the means; $\mathrm{BOD}=$ Biological oxygen demand; $\mathrm{pH}=$ Hydrogen ion concentration.

Table 2. Mean annual Secchi depth transparency and total dissolved solids in sampled water bodies in Benue State by sampling point (2012/2013).

\begin{tabular}{lcc}
\hline \multirow{3}{*}{ Sampling Point } & \multicolumn{2}{c}{ Water quality parameters } \\
\cline { 2 - 3 } & Secchi depth $(\mathbf{c m})$ & Total dissolved solids $(\mathbf{p p m})$ \\
\cline { 2 - 3 } & Mean \pm SE & Mean \pm SE \\
\hline UBP & $30.21 \pm 2.23^{\mathrm{c}}$ & $46.85 \pm 7.32^{\mathrm{a}}$ \\
PBP & $24.30 \pm 2.13^{\mathrm{a}}$ & $54.82 \pm 8.30^{\mathrm{c}}$ \\
DBP & $27.32 \pm 2.20^{\mathrm{ab}}$ & $51.68 \pm 7.81^{\mathrm{b}}$ \\
\hline
\end{tabular}

Means on the same column with the same superscript are not significantly different $(p=0.05)$. UBP $=$ Upstream of point of brick production; PBP $=$ Point of brick production; DPB $=$ Downstream of point of brick production; $\mathrm{SE}=\mathrm{Standard}$ error of the mean:

Table 3. Mean Secchi dept and total dissolved solids in water bodies in Benue State by season.

\begin{tabular}{lcc}
\hline Season & Transparency $(\mathbf{c m})$ & Total Dissolved Solids (ppm) \\
\cline { 2 - 3 } & Mean \pm SE & Mean \pm SE \\
\hline Dry & $36.50 \pm 2.09^{\mathrm{b}}$ & $72.73 \pm 7.82^{\mathrm{b}}$ \\
Wet & $18.13 \pm 0.53^{\mathrm{a}}$ & $29.49 \pm 3.22^{\mathrm{a}}$ \\
\hline
\end{tabular}

Means on the same column with the same superscript are not significantly different $(p<0.05)$.

and Gwer West were similar and did not differ significantly. The transparency of river waters from Konshisha, Ushongo and Vandeikya Local Governments did not differ significantly, but exhibited significant differences with water sampled from Gwer West and Kwande Local Government Areas. Also water transparency in Gboko, Makurdi and Kwande Local Government Areas differed significantly, between these Local Governments Areas (LGAs) themselves and between Buruku and Gwer West LGAs as well as.between Konshisha, Ushongo and Vandeikya LGAs.

Mean values of water transparency for the surveyed rivers/streams in Benue State taken at three sampling points, viz: UBP, PBP and DBP were $30.21 \pm 2.23$, $24.30 \pm 2.43$ and $27.32 \pm 2.20 \mathrm{~cm}$, respectively (Table 2 ).
There were significant differences between these values from the three sampling points. Mean coefficient of variation and Fisher's least significant difference for the state were 3.36 and 6.09 respectively. Mean dry and wet season values of water transparency were $36.50 \pm 2.09$ and $18.13 \pm 0.53 \mathrm{~cm}$, respectively, with co-efficient mean values for the dry season being significantly higher than those of the wet season (Table 3).

Mean values of Secchi depth for surveyed rivers ranged from $12.44 \pm 0.63$ to $50.29 \pm 5.85 \mathrm{~cm}$ for Gwer West and Kwande Local Government Areas respectively. Secchi depth values for Buruku and Gwer West LGAs were similar and did not vary significantly. The Secchi depth (transparency) of river waters from Konshisha, Ushongo and Vandeikya Local Government Areas did not vary 


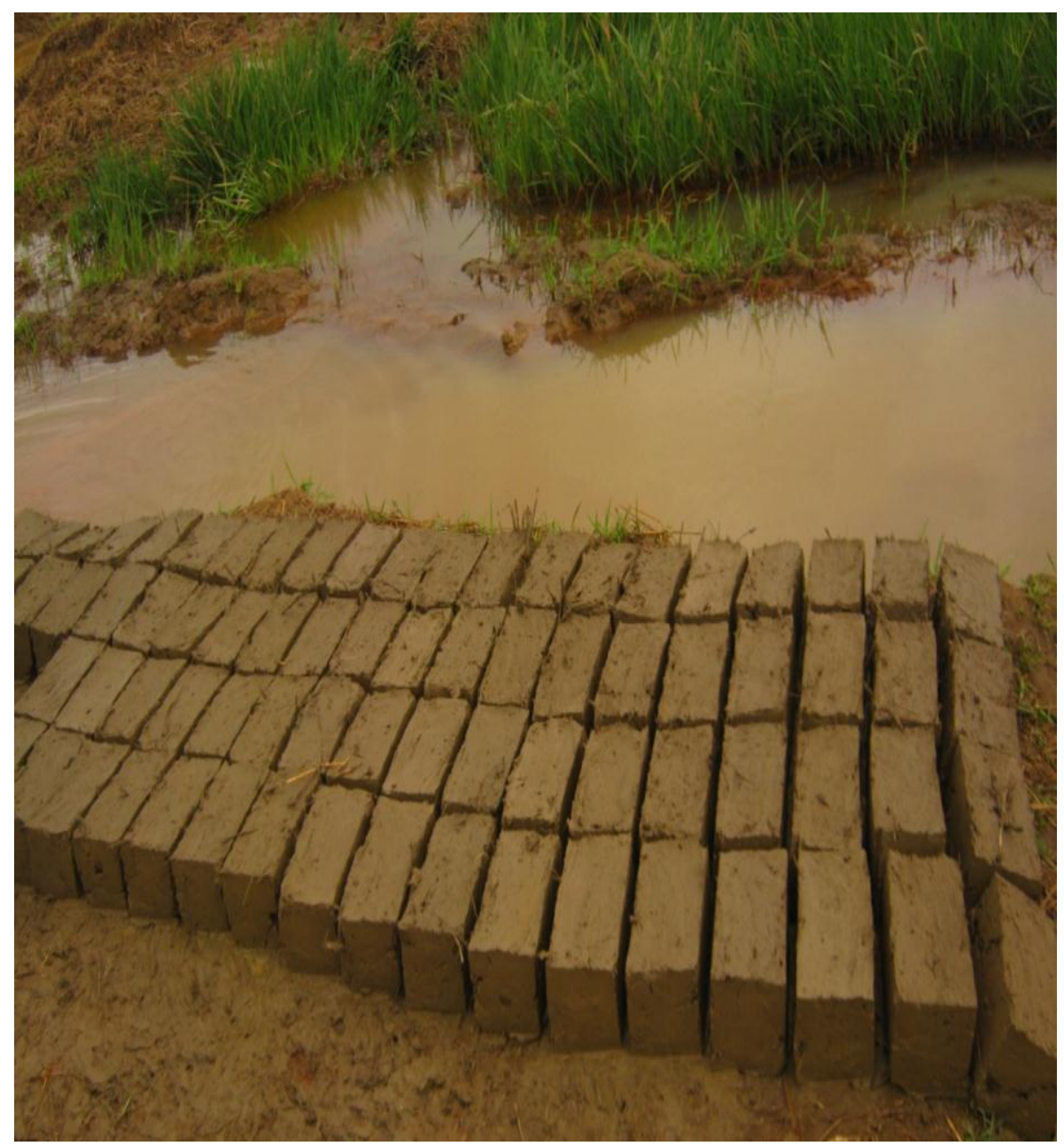

Plate 1. Freshly laid green bricks (or Adobe) (Absence of riprrian buffer strip protection accelerates deferestation and soil erosion along river banks).

significantly, but exhibited significant variation with water sampled from Gwer West and Kwande Local Government Areas. Also, water Secchi depth in Gboko, Makurdi and Kwande Local Governments showed significant variation, between these Local Governments themselves and the first two groups of local governments areas earlier mentioned.

Mean values of water transparency for all sampled rivers in Benue State taken at three sampling points, viz: upstream of point of brick production (UBP), point of brick production (PBP) and downstream of point of brick production (DBP) were $30.21 \pm 2.23,24.30 \pm 2.43$ and $27.32 \pm 2.20$, respectively. There were significant differences in the mean Secchi depth of these three categories of sampling stations. Mean dry and wet season values of Secchi depth for the entire study area were $36.50 \pm 2.09$ and $18.13 \pm 0.53$, respectively; these varied significantly from each other. Co-efficient of variation and least significant difference for the dry and wet season were 53.33 and 4.26, respectively. Secchi depth was lowest at point of brick production (PBP) station, followed by downstream of point of brick production (DBP) station and was highest at the upstream of point of brick production (UBP) station.

Plates 1 and 2 indicate that brick-production activities take place in Benue State without protection and conservation of vegetation along the rivers and streams. Vegetation adjourning burnt brick sites is indiscriminately removed. These activities result in increased soil erosion and the resulting increase in water sediments can decrease sechi depth and transparency in streams and rivers at burnt brick sites within the study area.

\section{DISCUSSION}

From Table 1, Secchi depth values were highest for rivers in Kwande Local Government Area (LGA) (50.29 \pm 5.85 $\mathrm{cm})$, followed by Makurdi LGA [36.48 $\pm 3.55 \mathrm{~cm}]$ during the dry season while the values were lowest in Gwer West LGA $[12.44 \pm 0.63 \mathrm{~cm}]$ followed by Buruku LGA $[18.39 \pm 0.78$ 


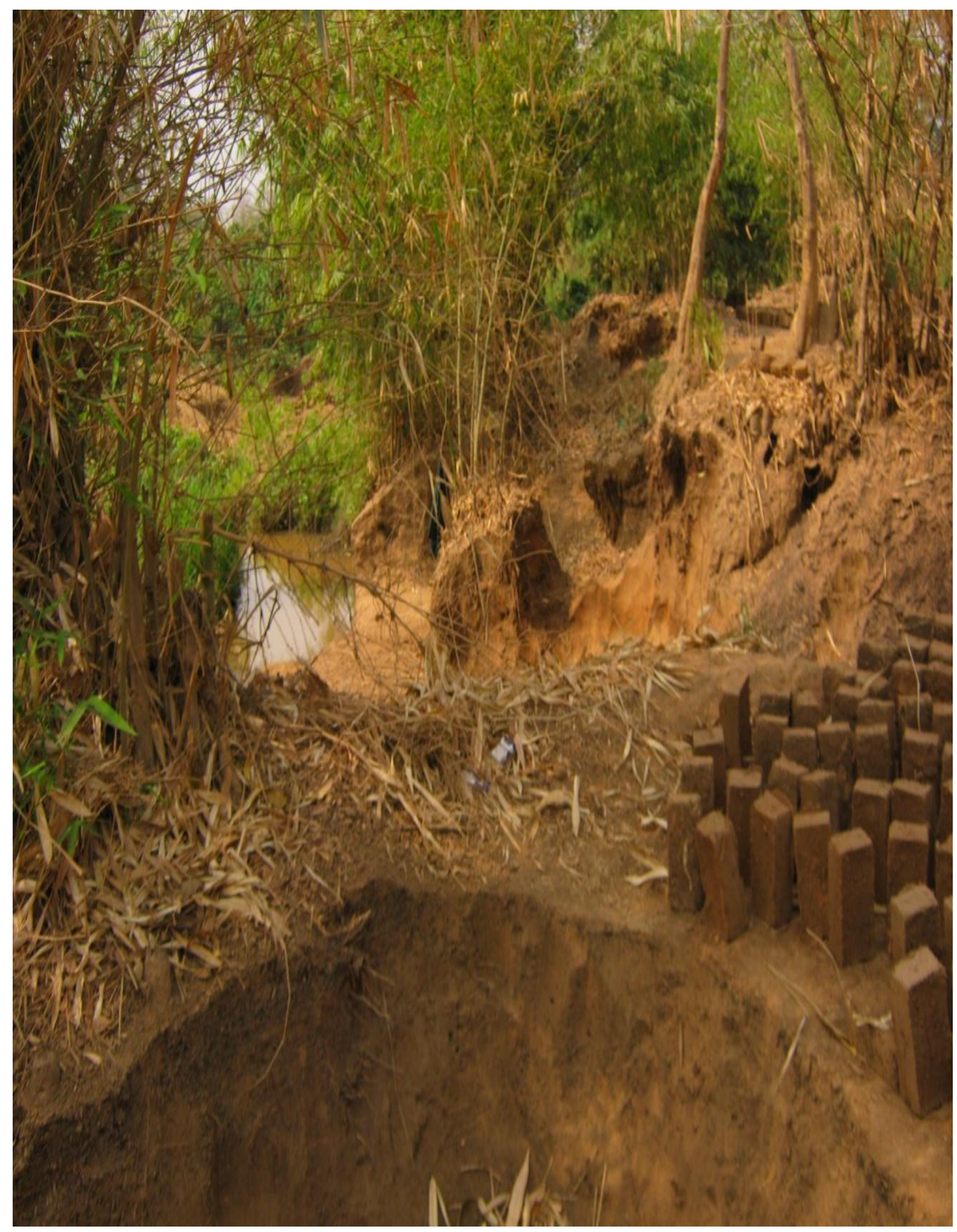

Plate 2. Changes in landscape resulting from soil excavation (Destroys riparian buffer strips, decreases water quality and aesthetic value of land and makes trees susceptible to damage from wind throw and water erosion).

$\mathrm{cm}$. However, values of total dissolved solids were highest in Gboko LGA [128.6 \pm 26.60 ppm] followed by Buruku LGA
[61.46 \pm 7.6$]$ while total dissolved solids had the lowest values for rivers in Kwande LGA [11.46 $\pm 0.73 \mathrm{ppm}]$ and 
Gwer West LGA [23.51 $\pm 0.82 \mathrm{ppm}]$. High Secchi depth values indicate that the water was more transparent, while lower Secchi Depth values implied that the water was less transparent (more turbid). Water containing higher total dissolved solids were less transparent compared to water bodies with a lower concentration of total dissolved solids. Secchi depth values were generally lower in the rainy season than the dry season implying that during the rainy season the water bodies in the study area had a higher concentration of total dissolved solids than during the dry season. Thus, the low secchi depth values corresponded to increased turbidity and a corresponding increase in total dissolved solids in rivers and streams. Increased TDS values coincided with the intensity of burnt brick activities.

It could be observed from Table 2 that mean Secchi depth values were much higher in sampling stations upstream of point of brick production (UBP) [30.21 \pm 2.23 $\mathrm{cm}$ ] followed by sampling stations downstream of point of brick production (DBP) while the sampling stations located at the points of brick production (PBP) had the lowest mean Secchi depth $(24.30 \pm 2.13 \mathrm{~cm})$. Total dissolved solids followed the same trend as Secchi depth at the sampling stations, being highest at the sampling stations PBP and lowest at UBP. These results imply that burnt brick production activities are highly implicated and thus responsible for increased TDS and reduced Secchi depth values during the dry and even wet seasons. During the wet (rainy) season however sediments from burnt brick production points are washed into rivers and streams adjourning the brick sites. Decreased water quality manifest in decreased Secchi depth and corresponding increase in TDS values characterized most sampling stations at PBP and the sampling stations downstream of point of brick production (DBP)

From Table 3, it could be observed that mean Secchi depth values were higher in the dry season $(36.50 \pm 2.0 \mathrm{~cm})$ compared to the wet season $(18.13 \pm 0.53 \mathrm{~cm})$ especially at the sampling stations PBP and DBP. At large burnt brick sites mean TDS values in the dry season $(72.73 \pm 7.82$ $\mathrm{ppm}$ ) were significantly higher than mean wet season TDS values $(29.49 \pm 3.22 \mathrm{ppm})$.

Burnt brick production involved activities like soil excavation, and vegetation clearing which could have impacted to reduce transparency in water bodies. Reduced Secchi depth also connotes that soil sediments produced through brick production activities could have made the water in rivers more turbid at the point of brick production, reducing the Secchi depth of such water bodies through increased water turbidity. Brick production can result in production of a lot of sediments. Soil exposure through vegetation clearing most likely increased insolation, organic matter degradation and increased soil erosion. In Gwer West and Buruku Local Governments Areas (LGAs) for example, Secchi depth values of the surveyed water bodies during the dry season were very low relative to significantly higher values in other Local Government Areas as a result of obnoxious fishing practices (like use of explosives, temporary damming and manual scooping of water to catch fish) and unrestrained human use of scarce water resource in the areas during the dry season in Gwer and Buruku LGA.

General increase in water Secchi depth values during the dry season could have emanated from reduced run-off water from bricks sites to rivers, and decrease in sediment concentration in the absence of river flooding which usually, actively assists transport of sediments in the wet season (Ibrahim et al., 2009). Adeyemi (2011) reported higher Secchi depth in the dry season in Gbadikere Lake. Akange and Araoye (2012) observed a significantly higher turbidity (implying lower Secchi depth) level in the rainy season compared to the dry season. Ibrahim et al. (2009) made similar observations in Kontagora reservoir. Lower Secchi depth recorded in the rainy season when there was turbulence and high turbidity, could precipitate corresponding low primary productivity because, turbidity reduces the amount of light penetration, which in turn reduces photosynthesis and hence primary productivity. Soil mining for brick production could lead to the removal of river channel substrate, re-suspension of streambed sediment, clearance of vegetation, and stockpiling on the streambed, precipitating ecological impacts. High levels of suspended solids may start to settle and alter the composition of the bed of the water bodies as it coats rocks and vegetation. This can affect the movement, feeding habits and reproduction of some macro-invertebrates (Adeyemo et al., 2008). Suspended and precipitated substances and organic substances in water are capable of adhering pollutant particles.

These sediments may have an effect on the direct loss of stream reserve habitat, disturbances of species attached to streambed deposits, reduced light penetration, reduced primary production, and reduced feeding opportunities (Adeyemi, 2009). Sediment is the most common pollutant washed from work sites (like brick sites), creating multiple problems once it leaves the work site. Sediment clogs the gills of fish, blocks light transmission and increases water temperature, all of which harm aquatic life. Sediment also blocks gutters and storm drains increasing the risk of flooding in areas downstream of the work site. Sediment also serves as a transport for other work site pollutants such as pesticides and cleaning solvents (Engineering Department, City of Walker, Michigan, 2012).

Sediment affects water quality physically, chemically, and biologically (Barbour et al., 1999). The varying chemical properties of pesticides - for example, their solubility, toxicity, and chemical breakdown rate determine the potential damage to water quality. Damage from sediment is expensive, both economically and environmentally. Sedimentation destroys fish spawning beds, reduces useful storage volume in reservoirs, clogs streams, and makes costly filtration necessary for municipal water supplies. Suspended sediment can reduce aquatic plant life and alter a stream's ecology 
(Cook et al., 1994).

Soil gets carried off by wind, water or gravity and then the topsoil is carried into rivers which can increase a river's water level. Soil also carries its toxicity with it so if pesticides were being used on that soil it will carry that into the water and pollute it. Contaminated soil from brick sites is a risk to public health and unstable soil can lead to landslips and dust storms. Burnt brick production contributes to problems such as soil erosion, fertility loss and compaction. The production places a significant demand on the organic and mineral components of soil. The minerals are typically removed more quickly than they can be replaced by natural processes. Hilly topography and active geology amplifies the problem of soil erosion. Land clearance and grazing on unstable lands contribute to this problem.

Brick production can lead to the run-off and leaching of nutrients into rivers, streams, estuaries and underground water. Where buffer strips are not protected during brick production processes, this can add sediment especially if operations lead to breaking down of stream banks. Nitrogen and phosphorus can end up in waterways from brick sites, making some aquatic plants and algae thrive. They then multiply and can damage native aquatic habitats, restrict swimming, boating and fishing, clog drains and hydro dam intakes, and thus spoil the aesthetic appeal of waterways.

Methods of harvesting woody biomass and excavating soil can impact water quality and quantity. For instance, soil excavation for brick production typically alters the shape of the land and changes the patterns of water flow in the area. Surface mining and deep mining of soil at brick sites can produce acid mine drainage, a flow of liquid that tends to be highly acidic and can contain high levels of potentially toxic metals (U.S. EPA, 2007). Harvesting wood for energy and other products can lead to soil erosion and runoff if proper management practices are not used. Healthy, well-managed riparian buffer zones, especially forested areas with steep slopes, are essential to maintaining clean rivers, streams, lakes, marshes, and groundwater.

\section{Conclusion}

There were significant differences between the dry and wet season Secchi depth (or transparency) of all water bodies from all sampled rivers/streams. During the dry season Secchi depth was lowest at the sampling points PBP followed by DBP, while UBP recorded the highest Secchi depth values for water bodies at burnt brick sites in Benue State. Total dissolved solids (TDS) followed the same trend as for Secchi depth. This implies that burnt bricks production lowers Secchi depth or transparency. Wet season figures of Secchi depth and TDS did not vary significantly between the sampling points PBP, DBP and UBP for the two years covered by this study.

\section{Recommendations}

1. There is need to spare riparian buffer strips along streams adjourning burnt brick sites as this can trap some of the sediment contained in running water during the rainy season.

2. Devegetated burnt brick sites need to be afforested to check erosion and decrease sediment resulting from brick production activities.

3. The current proliferation of burnt brick industries should be checked by establishing only bigger industries in areas that have the highest comparative advantage in terms of labour, natural and technological endowments.

\section{CONFLICT OF INTEREST}

The authors declare that they have no conflict of interest.

\section{ACKNOWLEDGEMENT}

The Department of Fisheries and Aquaculture, Federal University of Agriculture Makurdi provided technical advice and also calibrated and maintained the digital instrument used for this study. We quite appreciate the support of the then Head of Department of Fisheries and Aquaculture, Sr. J.O. Cheikyura.

\section{REFERENCES}

Adeyemi S. O. (2009). Fishery Ecology of Gbadikere Lake, Kogi StateNigeria. Unpublished Ph. D. Thesis, Benue State University, Makurdi.

Adeyemi S. O. (2011). Study of Some Physico-chemical Parameters and their Effects on Potential Fish Yield in Gbadikere Lake, Bassa, Kogi State, Nigeria. Pakistan Journal of Nutrition, 10(5), 475-479.

Adeyemo, O. K., Adedokun, O. A., Yusuf, R. K., \& Abeleye, E. A. (2008). Seasonal changes in physico-chemical parameters and nutrient load of river sediments in lbadan city, Nigeria. Global nest. The international journal, 10(3), 326-336.

Akange E. T., \& Araoye P. A. (2012). Seasonal physiochemistry of Lower River Benue, Nigeria. Caspian Journal of Applied Sciences Research, 1(5), 27-35.

Barbour, M. T, Gerrilsen, J., Synder, B. D., \& Stribling, J. B. (1999); Rapid bio-assessment protocols for use in Wadeable River-Periphyton, Lenthic Macro Invertibrates and Fish (2nd ed.). U.S. Environmental Protection Agency, Office of Water, EPA 841-B-99-002.

Cook, M. G., Zublena, J. P., Hodges, S. C., Naderman, G. C. (1994). Soils and Water quality. Factsheet. North Carolina Cooperative Extension Service.

Engineering Department (2012). The City of Walker Michigan, 4243 Remembrance Rd. NW Walker, Ml 49534 (616) 4536311.

Lee, G. F., Jones-Lee, A., \& Rast, W. (1995). Secchi depth as a water quality parameter (unpublished). 
Haggerty, J., \& Campbell, H. (2012). Farming and the environment - Effects on soil and water', Te Ara - the Encyclopedia of New Zealand, updated 13-Jul-12. Available at http://www.TeAra.govt.nz/en/farming-and-theenvironment/page-5

Ibrahim, B. U., Auta, J., \& Balogun, J. K. (2009). An Assessment of the Physico-Chemical Parameters of Kontagora Reservoir, Niger State, Nigeria. Bayero. Journal of Pure and Applied Sciences, 2(1), 64-69.

U.S. EPA (2007). Chesapeake Bay program. Annapolis, MD "Sediments".

Available http:?/www.chesapeakebay.net/sediments.aspx. Assessed on 22/8/2014.

Kumar, A., lakshmikanthan, K. R. L., \& Valdyanathan, G. (1998): Cleaner Brick Production in India: A Tran-sectoral Initiative. In: U.N.E.P, Industry and Environment, January - June, 1998. Pp. 77-80.
Morton, J. (1990). Brick. In Sowden, A. M. (ed.). The maintenance of brick and stone masonry structures. E. \& F. N. Spon, UK.

Saviour, M. N., \& Stalin, P. (2012). Soil and Sand Mining: Causes, Consequences and Management. IOSR Journal of Pharmacy (IOSRPHR), 2(4), 01-06.

Wikipedia (2011). Wikipedia: The Free Encyclopaedia -Burnt Bricks. Available at http//en.wikipedia.org. Accessed, 9th May, 2015. 